\title{
Nature and classification of special principles of national labour law
}

\author{
V. V.Ershov, E. A. Ershova \\ Russian State University of Justice, \\ 69, Novocheromushkinskaya ul., Moscow, 117418, Russian Federation
}

For citation: Ershov, Valentin V., Elena A. Ershova. 2021. "Nature and classification of special principles of national labour law". Vestnik of Saint Petersburg University. Law 1: 123-130.

https://doi.org/10.21638/spbu14.2021.108

\begin{abstract}
Most often, the principles of law in specialized literature are understood as the "initial principles", "ideas" and "provisions" of law. It seems that such conclusions could only be made from the standpoint of legal positivism, which restricts essentially "all" law only to the norms of labour law contained in national legal acts. The article makes a different conclusion: ontologically homogeneous elements are synthesized from the position of the scientifically substantiated concept of integrative legal understanding, first of all, the principles and norms of labour law contained in a single, developing and multilevel system of forms of national and (or) international labour law implemented in the state. With this theoretical approach, the principles of law can be controversially referred to as quite vague "principles," "ideas," and "positions". In support of their position, the authors of the article present several vivid examples of application of the Ruling No. 21 of the Plenary Session of the Supreme Court of the Russian Federation on June 2, 2015 "On Certain Issues that Arose in the Courts when Applying Legislation Governing the Work of the Head of the Organization and Members of the Collegial Executive Body of the Organization". The article provides an overview of ideas about the principles of law and their change in the pre-revolutionary, Soviet and modern periods. The authors emphasize that the special principles of national labour law are derived from the fundamental (general) principles of both national and international law which, by their nature, constitute undeniable law (jus cogens) binding on law-making and law-enforcement agencies as well as officials. The article advocates the position that the special principles of national labour law are the fundamental, primary elements of the labour law system that independently regulate labour relations in order to specify the norms of labour law.
\end{abstract}

Keywords: principles of law, jus cogens, labour law principles, legal positivism, integrative legal understanding, labour law system, forms of labour law, specification of labour law, nature principles of law, classification of principles of law.

\section{Introduction}

For many years, academic lawyers have been arguing not only about the content of the principles of law but also about the ways of classifying this phenomenon. According to K. N. Gusov and N. L. Lyutov, "the question of... principles is one of the most important and at the same time most debatable problems in law. The principles are most frequently understood as the initial principles (emphasis added) expressing the essence and social purpose of law" (Gusov, Lyutov 2015,26). At the same time, in Latin principium (princi-

(C) St. Petersburg State University, 2021 
ples) means the beginning, the basis of something. In this connection, the consideration of principles as bases is only a translation of the word principium into Russian.

However, in the general theory of law, E. A. Lukasheva in 1970 was one of the first in the USSR to define the principles of law as "objectively conditioned principles, ideas... (emphasis added)" (Lukasheva 1970, 22). In 1972 S. S. Alekseyev, on the one hand, partly repeated Lukasheva's conclusion, but, on the other hand, it seems that he developed a discussion point of view, repeatedly quoted in countless works. The principles of law, we believe, he argued controversially are "the initial normative and guiding principles expressed in law, characterizing its content, its foundations, the patterns of social life fixed in it. Principles are what permeates law, reveals its content in the form of initial, cross-cutting ideas, fundamentals, regulating and guiding provisions (emphasis added)" (Alekseyev 1972, 102).

It seems that similar conclusions could be drawn only from the standpoint of legal positivism restricting essentially "all" law only to the norms of law which are primarily contained in "legislation", or more precisely in national legal acts developed by public authorities. In the Legal encyclopaedic dictionary (Sukharev 1984), characteristically, the concept of "principles of law" was absent. In this connection, the final conclusion of A. V. Baranov made in 2016 is most significant: "....under the principles of law the basic, guiding provisions expressing the key essential features of the law are understood (emphasis added)" (Baranov 2016, 8). In this case, Baranov, first of all, referred to S. S. Alekseyev, P.T. Vaskov and I. Ya. Dyuryagin.

As a matter of legal positivism, many Soviet and Russian scientists did not consider the principles of law as an independent element of law regulating social relations. At best, the "rules-principles" of law were researched, which, according to Baranov, "represent a special kind of legal norms shaping the law system" (Baranov 2011, 5). In 2003 V. K. Babayev, from the standpoint of legal positivism, defined the rule-principles of law as "legislative prescriptions expressing and consolidating the principles of law (emphasis added)" (Babayev et al. 2003, 405). Finally, in 2016 Baranov clarified his point of view: "The principles of law, which have been directly consolidated in the text of regulatory legal provisions, are identified in legal literature as a special type of legal norms, namely the norms-principles that establish the essence of the legal position, the highest level of communication and abstraction (emphasis added)" (Baranov 2016, 8). At the same time, back in 1768 J. P. Kozelskiy convincingly believed that the principles of law were something unchangeable, just and universal and that the "commonly used laws" published in the state should always correspond to them (Kozelskiy 1959, 353-354). This conclusion was consistent with the point of view of foreign thinkers. Thus, Francis Bacon wrote brilliantly: "Principles are primary and simplest elements, from which everything else has been formed" (Bacon 1937, 22). Immanuel Kant highlighted the connecting nature of principles: "Principles are something containing the foundations of universal connection, which is a phenomenon" (Kant 1963, 340). Finally, G. W. F. Hegel convincingly and subtly remarked: "Principles are a single whole..." (Hegel 1970, 123).

\section{Basic research}

Nevertheless, the abovementioned conclusions of Soviet and Russian academics could not but find their reflection in the relevant national literature on labour law. Thus, V.V.Shishkin has traditionally and rather vaguely called his treatise "The constitutional 
foundations (principles) (emphasis added) regulating the labour of persons working under several employment agreements" (Shishkin 2014). In this treatise Shishkin wrote even less clearly: "The principles of law can be determined as the generalized requirements conditioned by the nature of the state and legal regulation to the system of social relations and the legal forms of their expression laying the moral and organizational basis for the emergence, development and functioning of law (emphasis added)" (Shishkin 2014, 8).

This term was seemingly coined on the basis of the scientifically controversial concept of integrative legal understanding which arguably synthesizes both law and other social phenomena, such as morality, in a single system (Ershov 2018, 53-81). In fact, firstly, what is the nature of the "generalized requirements"? Secondly, in our opinion, in the "system of social relations," or rather social phenomena, it is theoretically more accurate to distinguish between legal and other social phenomena, since not all "social ties" have a "legal form of expression". Thirdly, from the standpoint of a scientifically based concept of integrative legal understanding synthesizing only ontologically homogeneous and only legal phenomena in a single system of law, law and morality can be viewed as ontologically heterogeneous regulators of social relations that form various social systems. Later, Shishkin, quite tellingly, wrote in even more vague manner: "The principles of law as the initial principles (bases) specifying the most significant features of legal regulation act as a certain ideological basis (emphasis added) of a legal system reflecting the social purpose of law and the goals of legal regulation" (Shishkin 2014, 9).

D. Yu. Gladkikh traditionally defined the national principles of labour law as a system of the basic provisions of labour law conditioned by economic, political, social patterns taking the form of legal norms (international regulatory legal acts, the Constitution of the Russian Federation, labour legislation) or being derived from their content which reflect the essence, general orientation and tendencies of legal registration (regulation) of labour and other relations directly connected with them (Gladkikh 2002, 11). This understanding of the Russian labour law principles by Gladkikh poses a number of questions. For example, first, what is the nature of the "basic provisions of labour law"? Second, is it possible for the principles of labour law not to "take the form of" legal norms? Third, is it possible to determine the nature of "international regulatory legal acts"? Fourth, can the principles of labour law be "derived" only from the norms of labour law? Fifth, if so, what are the theoretical and legal arguments that allow such a conclusion to be made?

L. Yu. Bugrov, in our opinion, also and in a quite theoretic, controversial and vague way drew attention to the fact that "the principles of law are important for the implementation of law, especially for law enforcement practice, as they help in the interpretation of legislation, which promotes to fill the gaps in law, to overcome conflicts, to concretize, to interpret in a restrictive and excessive manner, to draw an analogy between law and legislation" (Bugrov 1992, 54). In the meantime, in our view, firstly, given the fact that, from the position of the scientifically substantiated concept of integrative legal understanding, the principles of law are the most important element of the system of national and (or) international law there is no ground to speak about the gap in law subject to the availability of legal principles (including the principles of national labour law), this gap is putative. Secondly, the principles of law, in particular the principles of national labour law, are a self-sufficient regulator of social relations independently governing labour relations, and not "promotes... to draw an analogy between law and legislation". 
N.V. Antipyeva in her turn also comes to the traditional conclusion: "The principles of social security law are the ideas laying the basis of law making (emphasis added) which have a decisive influence on the formation and development of legal relations aimed at protecting citizens from socially risky situations and their consequences, i. e. legal relations on social security of the population" (Antipyeva 2013, 9-10). At the same time, in our opinion, "ideas" cannot "have" a decisive influence on the formation and development of legal relations. In addition, the nature of the "impact" of ideas is also not entirely clear.

N.Sedova also traditionally but at the same time emphatically writes: "Under the principles of legal regulation of labour relations and other relations directly connected with them, it is necessary to understand the fundamental principles (ideas) enshrined in the current legislation expressing the essence of the norms of labour law (emphasis added) and the main directions of state policy in the field of legal regulation of public relations connected with the functioning of the labour market, the use and organization of wage labour" (Sedova 2013, 12). First of all, attention is drawn to the fact that Sedova, in accordance with legal positivism, restricts the principles of national labour law fixed only by the current "legislation". Hence the question arises, is it not possible for the principles of labour law to be contained, for example, in the customs of national law and Russian legal treaties? In addition, the paper of Sedova entitled "The fundamentals (principles) of labour law". At the same time, she writes for some reason in her paper: "the fundamentals (ideas)?!" Furthermore, Sedova consistently continues, from the standpoint of legal positivism: "branch principles of labour law express the general essential properties of the norms of the given branch of law (emphasis added)" (Sedova 2013, 13).

The most interesting paper in the study of the principles of national and international labour law in Russia today is apparently written by I. Yu. Voronov under the title of "The legal nature of the fundamental principles of the Russian labour law as a matter of legality and integrative legal understanding" (Voronov 2012). The author rightly noted that the principles of labour law to some extent were also studied by N.G. Alexandrov (Aleksandrov 1959, 48-50), A.E.Pasherstnik (Pasherstnik 1957, 100), R.Z.Livshits and V. I. Nikitinsky (Livshits, Nikitinsky 1974, 31-32), O. V.Smirnov (Smirnov 1977, 15) and I. K. Dmitrieva (Dmitrieva 2004b, 334). Thus, in her doctoral dissertation Dmitrieva persuasively emphasized the regulative role of the principles of national labour law and also differentiated the principles and norms of labour law (Dmitrieva 2004a, 579-580).

Voronov, from the point of view of integrative legal thinking, also came to a theoretically substantiated conclusion: "The fundamental principles of Russian labour law are applied directly, have a higher legal force over the norms of labour law contained in Russian normative legal acts, normative legal agreements and customs of Russian labour law" (Voronov 2012, 42). At the same time, Voronov left open the questions about the nature and classification of special national principles of labour law.

Many scholars often attribute a wide variety of social phenomena to the principles of law. In this regard, we would like to share the position of the Hungarian academician Imre Szabo, who wrote: "Some authors spot too many principles for each branch of law. This is due to the fact that such principles are presented as the features of the given branch of law, albeit specific to it, but, on the other hand, these features cannot be considered principles that are of a permanent nature, covering all the essential properties of this branch of law and conditioning its content and form of expression" (Szabo 1974, 74). 
For example, E. V. Ponomarenko in 2017 prepared an author's abstract of the Doctor of Law dissertation entitled "Legal development in the category of theory of law" in which she singled out, in our opinion, the following theoretically debatable and vague "principles" of law - "the freedom of legal knowledge and legal understanding for transformations in the legal system, the unity of values, the humanisation of the legal system, the social and cultural human development, advancing development as an independent human life in the law" (Ponomarenko 2017, 12).

K.L. Tomaszewski in his author's abstract of the Doctor of Law dissertation entitled "The system of sources of labour law of the Member States of the EAEU: theory and practice" also summarized and formulated ten, in his opinion, generally recognized "principles" of international law in the field of labour, for example, "freedom of speech" and "humanity (humanism)" (Tomaszewski 2017, 15).

It seems that first of all, law should be considered from the point of view of the scientifically substantiated concept of integrative legal understanding synthesizing only ontologically homogeneous elements, primarily the principles and norms of law contained in a single, developing and multilevel system of national and (or) international law forms implemented in the State (Ershov 2018).

With such a theoretical approach, the nature of the special national principles of Russian law, including the special principles of Russian labour law, is not described as quite vague "bases", "positions", "ideas", etc. From the standpoint of a scientifically based concept of integrative legal understanding, special principles of national law, in particular special principles of national labour law are the basic and primary elements of a single system of law (including the labour law system) that independently regulate relations between participants of disputed relations.

In ancient times it was stressed that "The principle is the most important part of everything". Thus, Aristotle understood the "principle" in the objective sense as the form of the first magnitude, something from which something exists or will exist (Kondakov 1975, 477). Therefore, the principles of national labour law are theoretically considered as a "special kind of legal norms", "legal provisions of the highest level of generalization and abstraction", "ideas", "bases", "provisions", etc. In our opinion, from the position of the scientifically substantiated concept of integrative legal understanding, the principles of national labour law are its independent and primary elements regulating labour relations.

In support of what has been said, we would like to mention two of the brightest examples, from our perspective, of the judicial practice reflected in Ruling No. 21 of the Plenary Session of the Supreme Court of the Russian Federation from June 2, 2015 "On Certain Issues that Arose in the Courts when Applying Legislation Governing the Work of the Head of the Organization and Members of the Collegial Executive Body of the Organization"1.

The first example is related to the use of Article 278 of the Labour Code of the Russian Federation. In accordance with this article, apart from the grounds provided for by the Labour Code and other federal laws, the employment agreement with the head of the organization is terminated on the grounds "not being a measure of legal responsibility", i. e., owing to the relevant decision adopted by the authorized body of a legal entity, or the

1 "Ruling No. 21 of the Plenary Session of the Supreme Court of the Russian Federation from June 2, 2015 'On Certain Issues that Arose in the Courts when Applying Legislation Governing the Work of the Head of the Organization and Members of the Collegial Executive Body of the Organization"'. 2015. Rossiiskaia gazeta 124. Accessed December 01, 2019. https://rg.ru/2015/06/10/vs-dok.html. (In Russian) 
owner of the organization's property or by the authorized person (body). In practice, such termination of the employment agreement in courts has traditionally been limited to the study of two issues. First - in what position did the plaintiff previously work? Second in accordance with which article of the Labour Code of the Russian Federation has his employment agreement been terminated? As a rule, in the case of an appropriate response to the questions posed, the claims submitted by the heads of organizations were dismissed. At the same time, in paragraph 3 of clause 9 of the abovementioned ruling of the Plenary Session of the Supreme Court of the Russian Federation the courts from the position of the scientifically substantiated concept of integrative legal understanding explained the following: "If the court finds that the decision to terminate the employment agreement with the head of the organization under clause 2 of Article 278 of the Labour Code of the Russian Federation was taken by the employer with violation of the principles of the inadmissibility of the abuse of rights and (or) the prohibition of discrimination in the workplace (Articles 1, 2, and 3 of the Labour Code of the Russian Federation), such a decision can be considered illegal (emphasis added)"2.

The second example concerns the application of Article 279 of the Labour Code of the Russian Federation which stipulates that "in the event of the termination of the employment agreement with the head of the organization in accordance with clause 2 of part 1 of Article 278 of this Code, in the absence of guilty actions (inactions) of the head, compensation is paid to him in the amount determined by the labour agreement, but not lower than three times the average monthly earnings". In practice, such payments, as a rule, were excessively high, and therefore were called "golden parachutes". In paragraph 2 of clause 11 of the ruling, the Plenary Session of the Supreme Court of the Russian Federation explained, from the position of a scientifically substantiated concept of integrative legal understanding, the following: "In case the conditions of the employment agreement infringe the requirements of legislation and other regulatory legal acts, including the general legal principle of the inadmissibility of abuse of law, legitimate interests of the organization, other employees, other persons (for example, the owner of the organization's property), the court is entitled to dismiss the claim for compensation from the employer in connection with the termination of the employment agreement or reduce its amount (emphasis added)"3.

\section{Conclusions}

One of the methods for deepening the understanding of the special principles of national law is their classification. The classification of special principles of national labour law can be made according to various criteria. Due to the limited scope of this article, we are forced to limit ourselves to the classification of the principles of national labour law only in the sphere of regulation of disputable relations. Thus, in the field of regulation of public relations in Russia it is possible to single out the fundamental (general) national and (or) international principles of law; fundamental (general) national and (or) international intersectoral principles of law; special principles of national and (or) international

2 "Ruling No. 21 of the Plenary Session of the Supreme Court of the Russian Federation from June 2, 2015 'On Certain Issues that Arose in the Courts when Applying Legislation Governing the Work of the Head of the Organization and Members of the Collegial Executive Body of the Organization"'. 2015. Rossiiskaia gazeta 124. Accessed December 01, 2019. https://rg.ru/2015/06/10/vs-dok.html. (In Russian)

${ }^{3}$ Ibid. 
labour law implemented in the state; special principles of individual institutions of national and (or) international law implemented in the state.

Following this theoretical approach, the special principles of national labour law become only one of the objectively existing elements of a single, developing and multilevel system of forms of national and (or) international labour law implemented in Russia. At the same time, M. Yu. Buyanova rightly noted: “...some representatives of the legal science express doubt in the legitimacy of the separation of the principles of the institutions of the field of law. They believe that all institutions are permeated with branch principles that ensure the inseparable connection of this institution with others" (Buyanova 2012, 6). However, according to the convincing conclusion of Buyanova "such judgments, at least, are very controversial. The institute is a universally recognized definition of the system of the branch of law, having its own separate circle of social relations (emphasis added)" (Buyanova 2012, 6).

In conclusion, we would like to emphasize that special principles of national labour law derive from the fundamental (general) principles of both national and international law. In our opinion, by their very nature the fundamental (general) principles of both international and national law are an indisputable right (jus cogens) binding for law making and law enforcement bodies as well as officials. Following such a theoretical approach, special principles and norms of national labour law should be developed (established, allocated, etc.) not on the basis of subjective discretion of the authorized state bodies and officials, as well as scientific and practical workers, but in order to specify the fundamental (general) principles of national and (or) international law (including labour law) which are an undisputed right (jus cogens).

\section{References}

Aleksandrov, Nikolai G. 1959. Soviet labour law. $2^{\text {nd }}$ ed. Moscow, Gosiurizdat Publ. (In Russian)

Alekseyev, Sergei S. 1972. Problems of the law theory. Basic issues of the socialist law general theory: lectures. In 2 vols. Sverdlovsk, Sverdlovsk Law Institute Publ. (In Russian)

Antipyeva, Natalia V. 2013. "Unity and differentiation of legal regulation as a principle of the social security right”. Iuridicheskie nauki 3: 8-16. (In Russian)

Babayev, Vladimir K., ed. 2003. Theory of state and law: textbook. Moscow, Iurait Publ. (In Russian)

Bacon, Frencis. 1937. On principles and bases. Moscow, Sotsekgiz Publ. (In Russian)

Baranov, Andrei V. 2011. "System-specific specialized norms of law in the mechanism of legal regulation". Vestnik Tomskogo gosudarstvennogo universiteta. Pravo 2: 5-12. (In Russian)

Baranov, Andrei V. 2016. "Norms-principles in the mechanism of legal regulation". Vestnik Tomskogo gosudarstvennogo universiteta. Pravo 4 (22): 5-14. (In Russian)

Bugrov, Leonid Yu. 1992. Gaps in freedom of labour in the labour law of Russia. Perm, Permskii universitet Publ., INPEA Publ. (In Russian)

Buyanova, Marina O. 2012. "Principles of the institute of social services". Pravo i gosudarstvo 8: 6-10. (In Russian)

Dmitrieva, Irina K. 2004a. “Basic principles of labour law”. Dr. Sci. diss., Moskovskii gosudarstvennyi universitet. (In Russian)

Dmitrieva, Irina K. 2004b. Principles of Russian labour law: monograph. Moscow, Rossiiskaia pravovaia akademiia Ministerstva iustitsii Rossiiskoi Federatsii Publ. (In Russian)

Ershov, Valentin. V. 2018. Legal and individual regulation of public relations. Monograph. Moscow, Rossiiskii gosudarstvennyi universitet pravosudiia Publ. (In Russian)

Gladkikh, Denis Yu. 2002. "The impact of the principles of labour law on the legal regulation of labour relations in the internal affairs bodies". PhD abstract, Permskii gosudarstvennyi universitet. (In Russian) 
Gusov, Kantemir N., Nikita L. Lyutov. 2015. International labour law: textbook. Moscow, Prospekt Publ. (In Russian)

Hegel, Georg. 1970. Science of logic: in 3 vols. Vol. 1. Moscow, Mysl' Publ. (In Russian)

Kant, Immanuel. 1963. Essays: in 6 vols. Vol. 1. Moscow, Mysl' Publ. (In Russian)

Kondakov, Nikolai I. 1975. Logic dictionary-directory. Moscow, Nauka Publ. (In Russian)

Kozelskiy, Jakov P. 1959. Philosophic assumptions. Legal works by progressive Russian thinkers. Moscow, Gosiurizdat Publ. (In Russian)

Sukharev, Aleksandr Ya., ed. 1984. Legal encyclopaedic dictionary. Moscow: Sovetskaia entsiklopediia Publ. (In Russian)

Livshits, Roman Z., Vasilii I. Nikitinsky 1974. "Principles of Soviet labour law”. Sovetskoe gosudarstvo i pravo 8: 31-39. (In Russian)

Lukasheva, Elena A. 1970. "Principles of socialist law”. Sovetskoe gosudarstvo i pravo 6: 21-29. (In Russian)

Pasherstnik, Aron E. 1957. "On the scope and principles of Soviet labour law”. Sovetskoe gosudarstvo i pravo 10: 92-103. (In Russian)

Ponomarenko, Elena V. 2017. "Legal development in the category of law theory”. Dr. Sci. diss., Ural'skaia gosudarstvennaia iuridicheskaia akademiia. (In Russian)

Sedova, Natalia. 2013. “The bases (principles) of labour law”. Voroosy trudovogo prava 3: 12-31. (In Russian)

Shishkin, Vladimir V. 2014. The constitutional foundations (principles) regulating the labour of persons working under several employment agreements. Moscow, Iurlitinform Publ. (In Russian)

Smirnov, Oleg V. 1977. Basic principles of Soviet labour law. Moscow, Iuridicheskaia literatura Publ. (In Russian)

Szabo, Imre. 1974. Foundations of law theory. Rus. ed. Moscow, Progress Publ. (In Russian)

Tomaszewski, Kirill L. 2017. "The system of sources of labour law of the Member States of the EAEU: theory and practice". Dr. Sci. abstract, Moskovskaia gosudarstvennaia iuridicheskaia akademiia imeni O. E. Kutafina. (In Russian)

Voronov, Igor' Yu. 2012. “The legal nature of the fundamental principles of the Russian labour law as a matter of legality and integrative legal understanding”. Rossiiskoe pravosudie 4: 35-46. (In Russian)

Received: June 21, 2020

Accepted: December 17, 2020

\section{Authors'information:}

Valentin V.Ershov — Dr. Sci. in Law, Professor; evv@rsuj.ru

Elena A.Ershova - Dr. Sci. in Law, Professor; evv@rsuj.ru 